\title{
Cost-effectiveness of pulse-echo ultrasonometry in osteoporosis management
}

This article was published in the following Dove Press journal: ClinicoEconomics and Outcomes Research

\section{Erkki Soini' \\ Ossi Riekkinen ${ }^{2}$ \\ Heikki Kröger ${ }^{3,4}$ \\ Petri Mankinen' \\ Taru Hallinen' \\ Janne P Karjalainen ${ }^{2}$}

'ESiOR Oy, Kuopio, Finland; ' ${ }^{2}$ Bone Index, Kuopio, Finland; ${ }^{3}$ Kuopio Musculoskeletal Research Unit, University of Eastern Finland, Kuopio, Finland; ${ }^{4}$ Department of Orthopedics, Traumatology and Hand Surgery, Kuopio University Hospital, Kuopio, Finland
Correspondence: Erkki Soini

ESiOR Oy, Tulliportinkatu 2 LT4, Kuopio

70100 , Finland

Tel +35840053 397l

Email erkki.soini@esior.fi
Purpose: Osteoporosis is asymptomatic morbidity of the elderly which develops slowly over several years. Osteoporosis diagnosis has typically involved Fracture Risk Assessment (FRAX) followed by dual energy X-ray absorptiometry (DXA) in specialist care. Point-of-care pulseecho ultrasound (PEUS) was developed to overcome DXA-related access issues and to enable faster fracture prevention treatment (FPT) initiation. The objective of this study was to evaluate the cost-effectiveness of two proposed osteoporosis management (POMs: FRAX $\rightarrow$ PEUS-ifneeded $\rightarrow$ DXA-if-needed $\rightarrow$ FPT-if-needed) pathways including PEUS compared with the current osteoporosis management (FRAX $\rightarrow$ DXA-if-needed $\rightarrow$ FPT-if-needed).

Materials and methods: Event-based probabilistic cost-utility model with 10-year duration for osteoporosis management was developed. The model consists of a decision tree for the screening, testing, and diagnosis phase and is followed by a Markov model for the estimation of incidence of four fracture types and mortality. Five clinically relevant patient cohorts (potential primary FPT in women aged 75 or 85 years, secondary FPT in women aged 65, 75, or 85 years) were modeled in the Finnish setting. Generic alendronate FPT was used for those diagnosed with osteoporosis, including persistence overtime. Discounted (3\%/year) incremental costeffectiveness ratio was the primary outcome. Discounted quality-adjusted life-years (QALYs), payer costs (year 2016 value) at per patient and population level, and cost-effectiveness acceptability frontiers were modeled as secondary outcomes.

Results: POMs were cost-effective in all patient subgroups with noteworthy mean per patient cost savings of $€ 121 / 76$ (ranges $€ 107-132 / 52-96$ ) depending on the scope of PEUS result interpretation (test and diagnose/test only, respectively) and negligible differences in QALYs gained in comparison with current osteoporosis management. In the cost-effectiveness acceptability frontiers, POMs had $95 \%-100 \%$ probability of cost-effectiveness with willingness to pay $€ 24,406 / \mathrm{Q} A L Y$ gained. The results were robust in sensitivity analyses. Even when assuming a high cost of PEUS (up to $€ 110 /$ test), POMs were cost-effective in all cohorts.

Conclusion: The inclusion of PEUS to osteoporosis management pathway was cost-effective. Keywords: diagnostics, dual-energy X-ray absorptiometry, economic evaluation, Fracture Risk Assessment tool, PICOSTEPS, screening

\section{Introduction}

Osteoporosis is a typically asymptomatic morbidity of the elderly which develops slowly over several years. ${ }^{1-3}$ Osteoporosis weakens the bones through bone loss after the age of 40 years and increases bone loss after menopause and during the final years of life, making them fragile and more likely to break. Osteoporosis diagnosis often occurs only after a minor fall or sudden impact causes a bone fracture. ${ }^{4-6}$ Clinically, 
the World Health Organization defines osteoporosis with reference to bone mineral density. Bone mineral density in adults is usually denoted by its T-score relative to the peak bone mass distribution in healthy women aged 20-40 years, and a T-score $\leq-2.5$ indicates osteoporosis. ${ }^{7}$

Osteoporosis is a common illness with a prevalence estimate of 400,000 (around $7.3 \%$ of the population in the year $2016)^{8}$ in Finland. Each year, $\sim 6,000$ first and 1,000 repeat hip fractures and a total of 30,000-40,000 osteoporosis-related fractures occur ${ }^{5}$ mostly in patients without osteoporosis diagnosis. ${ }^{6}$ Although the incidences of some fractures have decreased in Finland (potentially due to improved functional ability, osteoporosis management, and other measures), ${ }^{9-12}$ there is an increase in incidence of some fractures. ${ }^{13-15}$ The fracture peak may be just emerging in countries such as Finland that had a high birth rate after the second world war, because the incidence of fractures increases exponentially with age. ${ }^{5}$ Globally, osteoporosis management is a concern in postmenopausal women. Approximately $40 \%$ of women and about $14 \%$ of men over 50 years of age will have a hip, vertebral or wrist fracture in their remaining lifetime. ${ }^{16-18}$

Besides the recommendation of adequate dietary calcium and vitamin D intake ${ }^{5}(211,833$ and 6,050 Finns with reimbursement for calcium and vitamin D in the year 2016, respectively), reimbursed fracture prevention treatments (FPTs) in Finland can include hormone replacement therapy (190,194 estrogen, 15,925 testosterone), bisphosphonates $(31,549$ : alendronate [22,028], risedronate [6,310], ibandronate [3,139], clodronate [229], zoledronic acid [54]), denosumab $(15,610)$, strontium ranelate $(530)$, teriparatide (457), and calcitonin (22). ${ }^{19}$ In osteoporosis management, two types of osteoporotic fracture prevention are distinguished: primary osteoporotic fracture prevention, which aims to prevent any osteoporosis-related fracture, and secondary osteoporotic fracture prevention, which aims to prevent subsequent osteoporosis-related fracture in osteoporotic individuals who have already suffered a fracture.

Osteoporosis testing of high-risk populations is effective. The high-risk populations for the testing include women aged $>65$ years with other risk factors such as heavy smoking or parental osteoporosis-related fracture; or individuals with fracture due to low-energy impact; comorbidities or pharmacologic therapies increasing osteoporosis risk; incidental observations on X-rays; or unexplained body height loss. ${ }^{5}$ However, identifying the high risk is difficult, and testing bone mineral density in all is not indicated. ${ }^{7}$ Recent guidelines ${ }^{4,5,20,21}$ and Finnish practice ${ }^{22}$ recommend that the 10-year fracture risk, estimated using the proprietary Fracture Risk
Assessment (FRAX) tool, ${ }^{23}$ should be used to screen potential osteoporosis for testing bone mineral density.

The medical need for effective on-site diagnostics is high, because around three-quarters of osteoporosis cases remain undiagnosed ${ }^{24}$ and many osteoporotic individuals are not identified until they experience fracture. Thus, potentially more than three-quarters of osteoporotic individuals do not receive any FPT. This is no surprise, as osteoporosis testing with the current methods alone is challenging. ${ }^{6}$

To overcome the limitations of using mostly radiographic, large diagnostic tools which are rarely available in primary care facilities, a novel handheld device based on the pulseecho ultrasound technology (pulse-echo ultrasonometry or ultrasonography [PEUS], Bindex ${ }^{\circledR}$; Bone Index Finland, Kuopio, Finland) was developed. ${ }^{25-29}$ PEUS is used as a point-of-care osteoporosis testing-diagnosis tool after FRAX screening and it can help avoid dual-energy X-ray absorptiometry (DXA) for most postmenopausal women. ${ }^{25,26,29}$ The bone mineral density estimates obtained using PEUS have correlated very well with those obtained with the DXA method ${ }^{26,28}$ and are associated with clinically confirmed fractures in the previous 5 years. ${ }^{25}$ The DXA has been the gold standard of choice in the bone mineral density-based diagnostics. $5,20,21,30$

The cost-effectiveness of current care-based conventional osteoporosis management (COM) $)^{4,5,7,20-22}$ and two proposed osteoporosis managements (POM) including FRAX screening, testing, diagnosis, and FPT if needed was modeled. Based on a literature search in the PubMed database, no assessments have been published on the subject matter. Overall, evidence-based health economic evaluations including the screening, testing, diagnosing, and FPT have been rarely conducted.

\section{Materials and methods}

The Patients-Intervention-Comparator-Outcome-SettingTime-Effects-Perspective-Sensitivity analysis (PICOSTEPS) principle was applied. ${ }^{31,32}$ PICOSTEPS is in line with a health technology assessment guideline prepared by the Finnish Medicines Agency, ${ }^{33}$ and Finnish official guidance for the cost-effectiveness analyses attached with pharmaceuticals reimbursement applications submitted to the Finnish Pharmaceuticals Pricing Board. ${ }^{34}$ Furthermore, PICOSTEPS describes the essential components of evidence-based health economic and outcomes research analytical framework in the order of importance. ${ }^{31}$

\section{Patients}

Five risk cohorts of postmenopausal women were modeled based on clinical rationale: women aged 65 years with 
secondary osteoporotic fracture prevention, and women aged 75 or 85 years with primary or secondary osteoporotic fracture prevention. ${ }^{5}$ The other characteristics were: T-score -2.8 (normal distribution, $95 \% \mathrm{CI}-3.1$ to -2.5 ) for osteoporotic and -0.25 (95\% CI -1.00 to 0.50$)$ for non-osteoporotic, ${ }^{23}$ and no parental hip fracture, oral glucocorticoid therapy, rheumatoid arthritis, or alcoholism. The potential events included hip (institutionalized to long-term care after the hip fracture or not institutionalized), vertebral, wrist, and other fractures.

\section{Intervention and comparator}

The cost-effectiveness of osteoporosis management pathways (Figure 1) was simulated in the osteoporosis screening-testing-diagnosis model, namely, the POM (FRAX followed by $(\rightarrow$ ) PEUS-if-needed $\rightarrow$ DXA-if-needed $\rightarrow$ FPT-if-needed) and

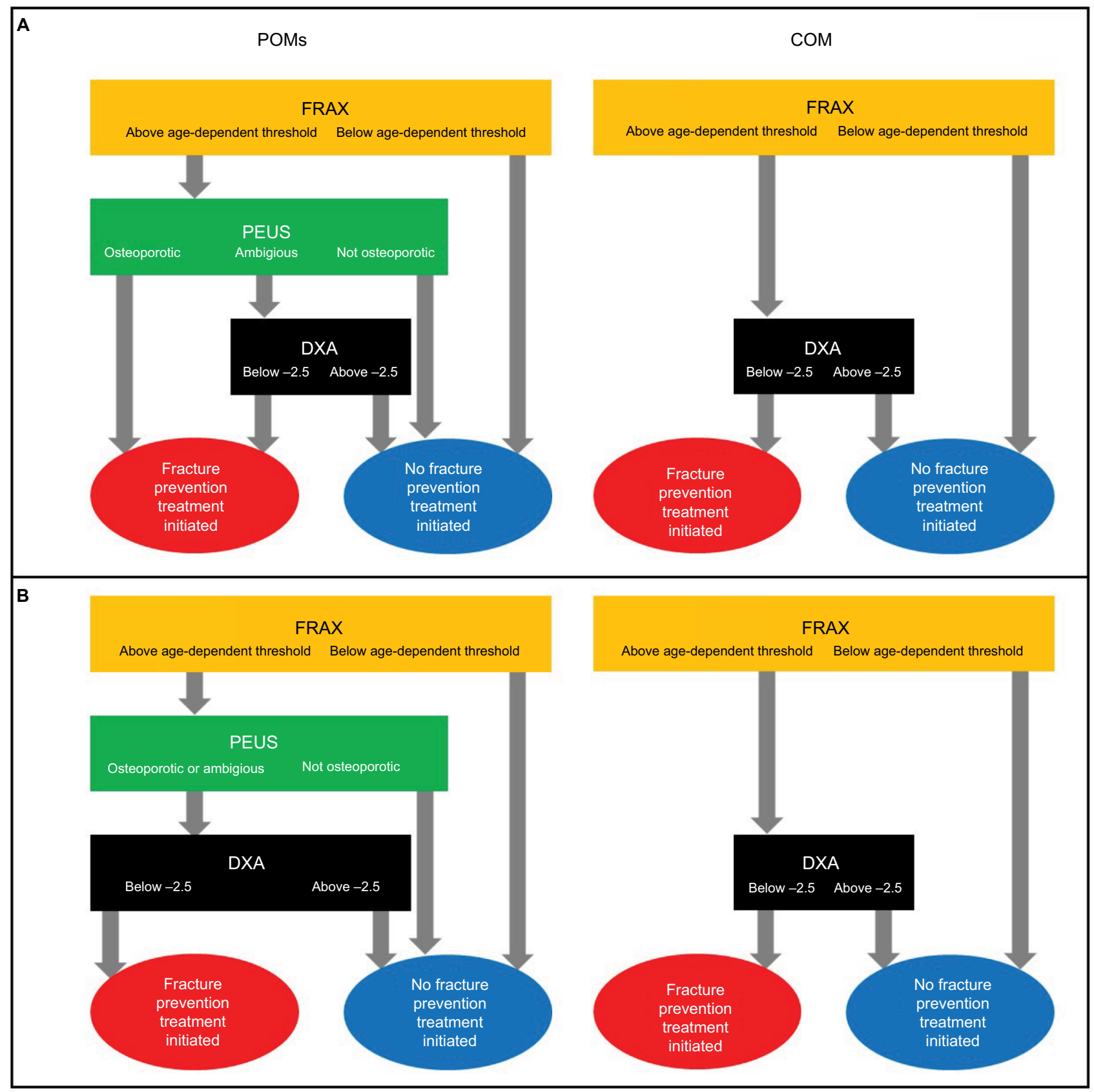

Figure I Decision tree: POM pathways are on the left-hand side and the COM pathway is on the right-hand side.

Notes: The upper part of $(\mathbf{A})$ presents the POMA strategy, where PEUS is used for osteoporosis testing and diagnosis. ${ }^{25-29}$ The lower part of (B) presents the alternative, POMB strategy, where PEUS is used for osteoporosis testing only and a positive diagnosis is confirmed with DXA.

Abbreviations: COM, conventional osteoporosis management; DXA, dual-energy X-ray absorptiometry; FRAX, Fracture Risk Assessment; PEUS, pulse-echo ultrasound technology; POM, proposed osteoporosis management; POMA, proposed osteoporosis management pathway A; POMB, proposed osteoporosis management pathway B. 
COM (FRAX $\rightarrow$ DXA-if-needed $\rightarrow$ FPT-if-needed). COM as a comparator was based on its clinical rationale and recommendation in Finland ${ }^{5}$ and elsewhere. ${ }^{4,7,20-22,30}$ POM was included as the intervention based on its results ${ }^{25-29}$ and potential affordability.

The need for PEUS and/or DXA in the model is based on the age-dependent FRAX, ${ }^{23}$ which predicts the 10 -year fracture risk to help the clinical decision making. ${ }^{5,23}$ If the 10 -year fracture risk exceeded the age-dependent threshold values of $5.9 \%$ (age 65-74 years), $11.7 \%$ (75-84), or 19.8\% (85-) in the FRAX screening, intermediate fracture risk was present and bone mineral density was assessed (i.e., the individual underwent PEUS and/or DXA). If the 10-year fracture risk was below the age-dependent threshold values in the FRAX screening, low fracture risk was present and lifestyle advice and reassurance were given.

\section{Outcome}

The key outcome of the analysis was an incremental costeffectiveness ratio: the difference in simulated costs divided by the difference in simulated effectiveness. Also, the mean costs and effectiveness were presented as secondary outcomes.

\section{Setting}

The event-based modeling approach with a clinical decision tree and a Markov extrapolation model ${ }^{35,36}$ was selected to capture all relevant data and to simulate $(5,000$ iterations) the comprehensive osteoporosis management in Finland using Microsoft Excel 2016 with Visual Basic for Applications. A decision tree analysis was done to model the screening-testing-diagnosis process preceding the potential initiation of FPT (Figure 1). A Markov modeling followed to assess the fractures and FPT (Figure 2). The event-based modeling strategy was carried out as follows: specify diagnosis and determine initial cohort distribution, define the natural history of the disease (i.e., events and their risks), apply relative risk modifiers (i.e., patient characteristics and treatments), compute costs and effectiveness, and run the simulation model.

\section{Testing and diagnosis: decision tree model}

The osteoporosis screening-testing-diagnosis decision tree model (Figure 1) included COM and POM, and their sensitivity and specificity. FRAX constituted the initial screening tool common to both pathways, ${ }^{23}$ with a mean accuracy rate of 1.000 (assumed normal 0.975-1.025 95\% CI).

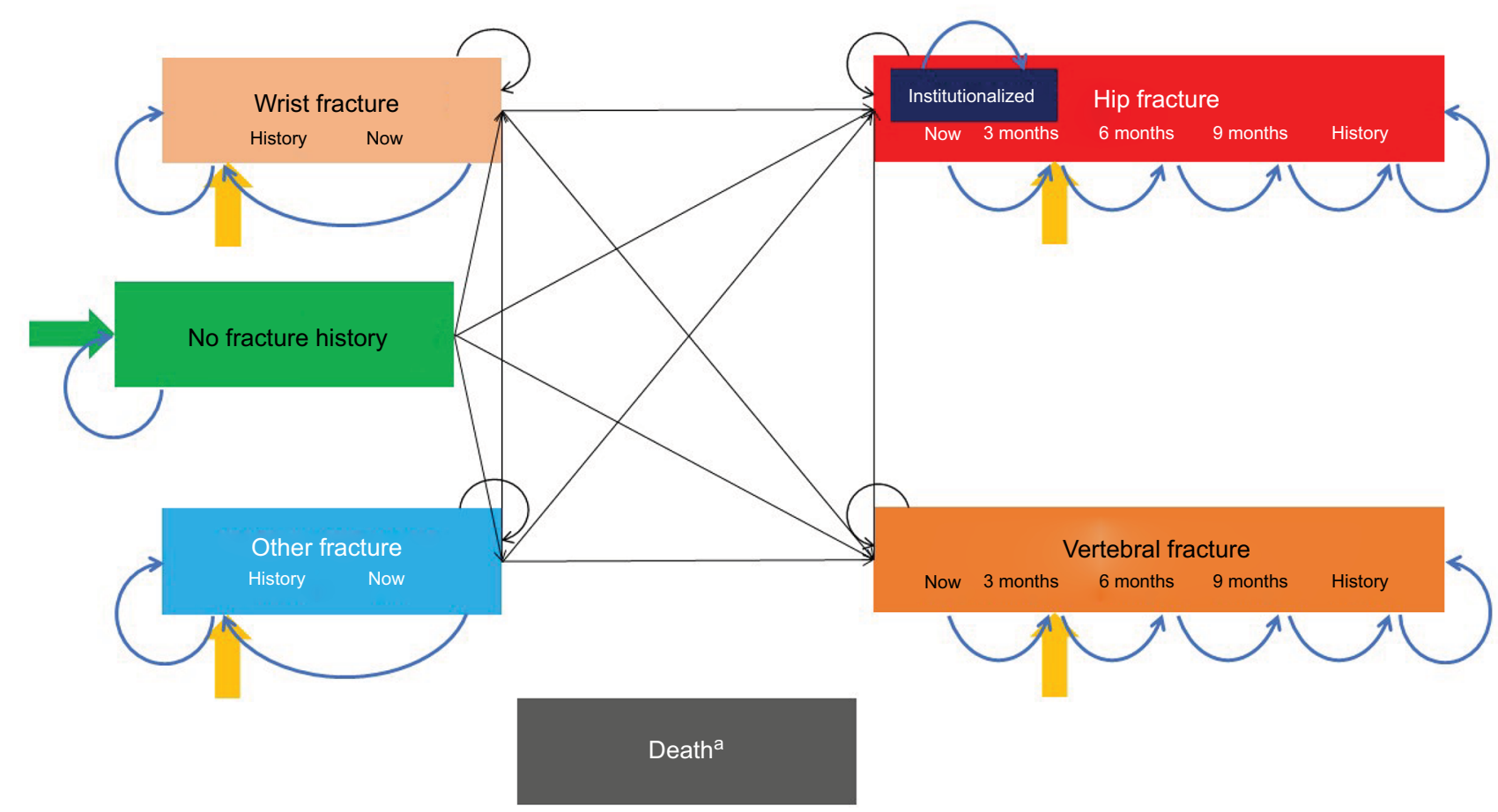

Figure 2 Markov model.

Notes: The bold green arrow points to the starting state of primary prevention of osteoporotic fractures, and the bold yellow arrows point to the starting state of secondary prevention. The black arrows correspond to fracture events, and the blue arrows indicate health-state transitions without new fractures. ${ }^{\mathrm{a}}$ Transitions to the absorbing dead state are possible from any state. 
In the decision tree, PEUS was calibrated to the $90 \%$ sensitivity-specificity threshold in accordance with the International Society for Clinical Densitometry guidelines ${ }^{37,38}$ and modeled using Dirichlet distribution (i.e., altogether $10 \%$ of PEUS results are false negatives or false positives and have incorrect osteoporosis management). Thus, cost-effectiveness analysis with correct and incorrect treatment pathways was needed to evaluate how much effectiveness is potentially lost when using the POM.

In the POM pathway A (POMA, Figure 1) of the decision tree, $32.6 \%$ of individuals have ambiguous PEUS results (between the $90 \%$ sensitivity-specificity calibration thresholds). ${ }^{26}$ These individuals require and are provided a DXA measurement to verify the diagnosis. A recent realworld study confirmed the proportion of ambiguous PEUS results with the need of sending $32.5 \%$ of individuals to DXA investigation after PEUS measurement. ${ }^{29}$ In POMA, both false positives and negatives occur up to $10 \%$ of the patients in total and are modeled accordingly. These results constituted initial cohort distribution for the Markov model in the case of POMA. Thus, in the POMA strategy, PEUS is used for osteoporosis testing and diagnosis, ${ }^{25-29}$ which is a potentially common strategy in the Finnish public sector based on the clinical and economic rationale.

In the POM pathway B (POMB, Figure 1) of the decision tree, both ambiguous and osteoporotic PEUS results require and receive a DXA measurement, which eliminates the false positives. These results constituted the initial cohort distribution for the Markov model in the case of POMB. Thus, in the POMB strategy, PEUS is used for osteoporosis testing only and a positive diagnosis is confirmed with DXA, which can be a potentially common strategy in, for example, the USA.

\section{Bone fractures and prevention: Markov model}

The fractures and FPT were modeled with a Markov state transition model. The transitions were determined by clinical outcomes and a hierarchy of fractures was assumed, with hip fractures being more serious than vertebral fractures, which were in turn more serious than wrist and other fractures (Figure 2). Due to the duration of the fractures and available data, the Markov model had a 3-month cycle. Hip and vertebral fractures were represented as tunnel states because their costs and mortality depended on the time since the fracture. A state was used to model the proportion of individuals who were permanently institutionalized after a hip fracture.

In osteoporosis, the fracture risk can be reduced through FPT. A review of postmenopausal osteoporosis FPTs has been recently published, ${ }^{39}$ and alendronate once weekly is recommended as the first-line FPT in Finland. ${ }^{5}$ In addition, generic alendronate is the most affordable $\mathrm{FPT}^{40}$ with a high number of reimbursements in Finland ${ }^{19}$ and it is also likely to be a cost-effective FPT.

\section{Time}

The modeling was limited to 10 years due to the age of most individuals, potential changes in the FPTs, and limited knowledge regarding the extrapolated effects beyond 10 years (FRAX represents 10-year risk). ${ }^{7,23}$ Conversions between rates and probabilities were performed using the common transformation methodology. ${ }^{41}$ The annual discounting rate of effectiveness and costs was $3 \%{ }^{33,34}$

\section{Effects}

The long-term Markov fracture and FPT modeling included hip, vertebra, wrist, and other fractures. Finnish FRAX collaboration data demonstrated the 10 -year risk of hip or any fracture in Finland per individual's age, bone mineral density (T-score), and number of risk factors. ${ }^{7,23}$ To find osteoporotic fractures, US-based data on the age- and sex-specific relative risk of fracture attributable to osteoporosis were used. ${ }^{42}$ Relative risk for fracture was increased in individuals with a prior fracture, which could be accounted for by using the FRAX risk lookup, where prior fracture is one of the risk factors. ${ }^{23}$ The age-dependent results on the fracture rates in the USA were then used to split the Finnish 10-year risk estimate of any fracture into component types of vertebra, wrist, or other fracture and modelled in the Markov model..$^{42}$ The fracture prevention Markov model concurred with the health states used in earlier evaluations. ${ }^{43}$ Furthermore, institutionalization risk to long-term facility after hip fracture was modeled based on the Finnish real-world evidence. ${ }^{44}$

Alendronate $70 \mathrm{mg}$ /week FPT was modeled for osteoporotic individuals. For them, the fracture occurrence was adjusted downward based on the distributional efficacy estimated from a published meta-analysis of FPT. ${ }^{45,46} \mathrm{Sub}$ optimal FPT uptake (adherence) based on 20\% adherence at 5 years modified the efficacy through persistence to mimic the real-world situation. ${ }^{47,46}$ In line with this modeling study, the study included postmenopausal women, naive to bisphosphonates, who received a first prescription of alendronate. ${ }^{47}$ No rebound was assumed (i.e., FPT effect stops at the time of FPT discontinuation; Table 1).

The individuals can die from any health state. The background mortality was modeled based on the year 2016 official Finnish mortality statistics, ${ }^{48}$ excluding deaths due to osteoporosis (10th revision of the International Statistical 
Table I Effect estimates, $\mathrm{Cl}$ or SEs, and distributions applied

\begin{tabular}{|c|c|c|c|c|}
\hline Primary/secondary prevention & Relative risk & $95 \% \mathrm{Cl}$ & & Distribution \\
\hline Hip fracture ${ }^{45,46}$ & $0.66 / 0.49$ & $0.30 / 0.24$ & I.54/I.0I & Lognormal from $95 \% \mathrm{Cl}$ \\
\hline Vertebral fracture ${ }^{45,46}$ & $0.60^{\mathrm{a}} / 0.53^{\mathrm{a}}$ & $0.43 / 0.41$ & $0.80 / 0.68$ & Lognormal from $95 \% \mathrm{Cl}$ \\
\hline Wrist fracture ${ }^{45,46}$ & $0.67 / 0.52^{\mathrm{a}}$ & $0.19 / 0.33$ & $2.32 / 0.92$ & Lognormal from $95 \% \mathrm{Cl}$ \\
\hline Other fracture ${ }^{45,46}$ & $0.80^{\mathrm{a}} / 0.99$ & $0.67 / 0.76$ & $0.97 / 1.29$ & Lognormal from $95 \% \mathrm{Cl}$ \\
\hline Institutionalized & Probability & SE & & Distribution \\
\hline After hip fracture ${ }^{44}$ & 0.148 & 0.100 & & Uniform $\pm P 2 \%$ \\
\hline FPT & Probability & SE & & Distribution \\
\hline Start FPT if osteoporosis (assumption) & 1.000 & 0.000 & & Uniform $\pm P 2 \%$ \\
\hline Continue FPT per year ${ }^{47,46}$ & 0.725 & 0.100 & & Uniform $\pm P 2 \%$ \\
\hline HRQoL without fracture ${ }^{51}$ & Mean & $S E$ & & Distribution \\
\hline 65-74 years & 0.842 & 0.010 & & Normal with SE \\
\hline 75-84 years & 0.808 & 0.013 & & Normal with SE \\
\hline $85+$ years & 0.685 & 0.030 & & Normal with SE \\
\hline Disutility to $H R Q o L$ & Mean & $S E$ & & Distribution \\
\hline Alendronate use (assumption) & -0.010 & 0.010 & & Uniform $\pm P 2$ \\
\hline Multiplicative HRQoL decrement $t^{52}$ & Relative risk & $a$ & $\beta$ & Distribution \\
\hline Hip fracture, first/subsequent year & $0.797 / 0.899$ & $655 / 2,007$ & $167 / 225$ & Beta \\
\hline Vertebral fracture, first/subsequent year & $0.720 / 0.931$ & $169 / 1,021$ & $66 / 76$ & Beta \\
\hline Wrist or other fracture, first 3 months & $0.940 / 0.910$ & $326 / 318$ & $21 / 31$ & Beta \\
\hline
\end{tabular}

Note: aStatistically credible effect as the FPT was based on the $95 \% \mathrm{Cl}$.

Abbreviations: FPT, fracture prevention treatment (alendronate); HRQoL, health-related quality of life; SE, standard error; Cl, confidence interval.

Classification of Diseases codes M80 or M81). ${ }^{48,49}$ The FPT had an indirect effect through fractures to mortality. An elevated mortality relative risk of 4.53 during the first 6 months after the hip or vertebral fracture (1.75 in the subsequent 6 months and 1.78 thereafter) was modeled. ${ }^{50,42}$ Wrist or other fractures were not considered to increase mortality.

Finally, health-related quality of life was modeled using nationally representative age-, income-, education-, marital status-, and morbidity-adjusted Finnish EuroQol 5-dimensional 3-level scores for women based on a Tobit model, ${ }^{51}$ and multiplicative health-related quality of life losses associated with the fractures. ${ }^{46,52}$ The EuroQol 5-dimensional 3-level scores used represent the most suitable health-related quality of life for a postmenopausal woman available for the Finnish modeling purposes. Alendronate use was conservatively assumed to be associated with reduction in health-related quality of life (Table 1).

\section{Perspective}

The analysis included direct costs based on the Finnish guidance, ${ }^{33,34}$ and applied third-party payer perspective common in the guidance of many European countries. ${ }^{53-62}$ The analysis included direct health-related costs (e.g., patient co-payments, FPTs, treatments, visits, hospitalizations,

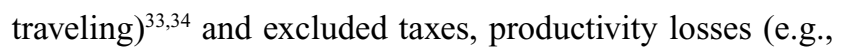

absenteeism, presenteeism, sickness allowances, pensions), other income transfers, and time costs.

\section{Costs}

The Finnish weekly cost of the most affordable generic alendronate $70 \mathrm{mg}$ was $€ 1.70$, excluding value-added tax. ${ }^{40}$ Fracture-associated costs were estimated based on the Finnish resource use in a representative national register study, ${ }^{44}$ which was valued with the national Finnish unit costs ${ }^{63}$ according to real values in the year 2016 (Table 2). ${ }^{64}$ The national health care $\operatorname{costs}^{63}$ were converted to year 2016 values using the latest official Finnish Communal Expenses Index for health care. ${ }^{64}$ Traveling costs ${ }^{65}$ were converted to 2016 real values using the transportation section of the latest official Finnish Consumer Price Index. ${ }^{66}$ Due to lack of data, a recursive fracture was considered to have the same costs and consequences as the first fracture.

Proprietary FRAX was available free of charge. ${ }^{23}$ Finnish year 2016 price lists of hospital districts were searched to find the prices of DXA measurements. A price of $€ 268$ (incl. visit price) could be a representative input value (i.e., average of most affordable prices per district incl. visit was $€ 297.50$ ), with the lowest (€124.00, probably not feasible) and highest (€476.00) costs. The mean cost of specialist visit and the mean cost of DXA measurement alone would be $€ 313.76$ and $€ 67.50$, respectively, that is, a total of $€ 381.26$. However, 
Table 2 Fracture costs (€, in the year 2016 real value)

\begin{tabular}{|c|c|c|c|c|}
\hline State, unit & Resource & Weighting basis ${ }^{63}$ & Weighted cost $t^{63, a}$ & Cost/event $^{b}$ \\
\hline \multirow[t]{4}{*}{ Hip fracture, months I-3 } & $44.0 \%$ artificial joint ${ }^{44}$ & DRG 209B-C & $8,150.73$ & $7,760.47$ \\
\hline & $49.3 \%$ other surgery ${ }^{44}$ & DRG 2I0-21। & $7,436.07$ & \\
\hline & $6.7 \%$ without surgery: index & $996.20 /$ day & $7,584.58$ & \\
\hline & hospitalization 7.1 days $^{44}$ & & & \\
\hline Institutionalized, per 3 months & 91.31 days & II5.00/day & 123.32 & $11,260.66$ \\
\hline \multirow{5}{*}{$\begin{array}{l}\text { Hip fracture history, months } \\
4-6,7-9,10-12^{c}\end{array}$} & 8.2 days of specialist hospitalization, & $996.20 /$ day & $8,759.65$ & $5,511.27$ \\
\hline & index hospitalization excluded, ${ }^{44} 33.3 \%$ & & & \\
\hline & based on clinical experience & & & \\
\hline & $\begin{array}{l}60.4 \text { primary care days, }{ }^{44} 33.3 \% \text { based on } \\
\text { clinical experience }\end{array}$ & $115.00 /$ day & $7,448.53$ & \\
\hline & $\begin{array}{l}2.9 \text { primary care visits }{ }^{44} 33.3 \% \text { based on } \\
\text { clinical experience }\end{array}$ & II0.00/visit & 342.08 & \\
\hline Vertebral fracture, months $I-3$ & & DRG $214 \mathrm{~A}-\mathrm{C}, 2 \mathrm{I} \mathrm{A}-\mathrm{C}$ & $7,038.51$ & $7,038.51$ \\
\hline $\begin{array}{l}\text { Vertebral fracture, months } 4-6 \text {, } \\
7-9,10-12^{c}\end{array}$ & $\begin{array}{l}\text { Derived proportionally: hip fracture } \\
\text { costs in months } 4-6 \text { vs. I-3 }\end{array}$ & DRG $214 \mathrm{~A}-\mathrm{C}, 2 \mathrm{I} \mathrm{A}-\mathrm{C}$ & Proportionally $4,998.55$ & $4,998.55$ \\
\hline Wrist or other fracture, & & DRG $218-219,223,225 A-B$ & $3,157.59$ & $3,157.59$ \\
\hline months $\mathrm{I}-3^{\mathrm{c}}$ & & $\begin{array}{l}\text { DRG 235-236, 250-25I, } \\
253-254\end{array}$ & & \\
\hline
\end{tabular}

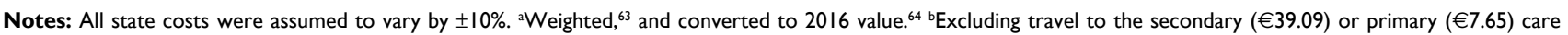
location that was included in the modeling. $65,66 \mathrm{c}$ No additional costs were included for the subsequent years after hip or vertebral fracture or for the subsequent months after wrist or other fracture.

Abbreviation: DRG, diagnosis-related group.

for conservative results, $€ 87.00$ was used as the base case input for DXA cost. Thus, the total cost of DXA included one primary care doctor visit and travel $(€ 133.26)$, the DXA test (€87.00, excluding visit) on the official Finnish price lists for communal invoicing, travels (€78.18), ${ }^{65,66}$ call $(€ 27.88)$, and statement $(€ 21.45){ }^{63,64}$

The total cost of the PEUS single-site test included primary care nurse visit and travel $(€ 66.77),{ }^{63-66}$ call $(€ 27.88)$ and statement (€21.45), ${ }^{63,64}$ and PEUS test (€50.00), and the total cost of the DXA specified above for the proportion of individuals undergoing the DXA in POM. The assumed cost of PEUS may overestimate the true PEUS cost to Finnish health care.

\section{Willingness to pay}

A complicating factor when interpreting the results of costeffectiveness analysis in the Finnish setting is the lack of an official willingness-to-pay threshold, ${ }^{67-69}$ a specific limit for additional investment to an additional quality-adjusted life year (QALY) gained.

In the UK, the most plausible willingness-to-pay threshold in non-end-of-life situations is $£ 20,000^{60}(€ 24,406$, mean exchange rate $€ 1=£ 0.81948$ in the year 2016), ${ }^{70}$ or maybe, in some cases, up to $£ 30,000(€ 36,609)$ per QALY gained. ${ }^{60,70}$ These willingness-to-pay thresholds may also be valid for the screening-testing-diagnosing-osteoporotic fracture prevention if needed process in Finland. ${ }^{67-69}$

\section{Sensitivity}

The robustness of results was tested using one-way and multiway sensitivity analysis scenarios. These included Patient, Setting, and Effects.

The sensitivity of probabilistic analysis was implemented based on distributions, and results were depicted in terms of a cost-effectiveness acceptability frontier. ${ }^{71}$ The frontier showed the optimal strategies with the highest expected monetary net benefit (pay-off) as a function of willingness to pay.

\section{Results}

The average absolute costs saved with POMA vs. COM were $€ 121 /$ patient $(1.3 \%$ ), ranging from $€ 107 /$ patient ( 75 years old, primary or secondary osteoporotic fracture prevention) to $€ 132$ patient ( 85 years old, secondary osteoporotic fracture prevention). The relative savings with POMA ranged from $1.0 \%$ patient ( 75 years old, secondary osteoporotic fracture prevention) to $1.7 \%$ /patient (65 years old, secondary osteoporotic fracture prevention). The average absolute costs saved with POMB vs. COM were $€ 76$ /patient (0.8\%), ranging from $€ 52 /$ patient $(0.5 \% ; 75$ years old, secondary osteoporotic fracture prevention) to $€ 96 /$ patient $(1.1 \%$; 85 years old, primary osteoporotic fracture prevention), as shown in Table 3.

In a setting of 40,000 tested women per year, POMA could result in potential annual cost savings of around $€ 4.8$ million (range $€ 4.3-5.3$ million depending on the 
Table 3 Ten-year base case results with 3\% per annum discounting: COM pathway vs. POM pathways

\begin{tabular}{|c|c|c|c|c|c|c|}
\hline \multirow{2}{*}{$\frac{\text { Age (years), cohort }}{65, \text { SOFPT }}$} & \multicolumn{3}{|c|}{ POMA: PEUS used for testing and diagnosis } & \multicolumn{3}{|c|}{ POMB: PEUS used for testing only } \\
\hline & Costs $(€)$ & QALYs & CE verdict & Costs $(€)$ & QALYs & CE verdict \\
\hline $\operatorname{COM}$ & 7,581 & 6.802 & ICER $307,527^{\mathrm{a}}$ & 7,565 & 6.805 & Dominated $^{b}$ \\
\hline POM & 7,451 & 6.802 & Most affordable & 7,502 & 6.806 & Most affordable \\
\hline 75, POFPT & Costs $(€)$ & QALYs & CE verdict & Costs $(€)$ & QALYs & CE verdict \\
\hline COM & 9,638 & 5.701 & ICER $60,478^{\mathrm{a}}$ & 9,748 & 5.697 & Dominated ${ }^{\mathrm{b}}$ \\
\hline POM & 9,531 & 5.699 & Most affordable & 9,668 & 5.697 & Most affordable \\
\hline 75, SOFPT & Costs $(€)$ & QALYs & $C E$ verdict & Costs $(€)$ & QALYs & $C E$ verdict \\
\hline COM & 10,280 & 5.684 & ICER $87,808^{a}$ & 10,147 & 5.698 & Dominated ${ }^{\mathrm{b}}$ \\
\hline POM & 10,173 & 5.683 & Most affordable & 10,094 & 5.699 & Most affordable \\
\hline 85, POFPT & Costs $(€)$ & QALYs & CE verdict & Costs $(€)$ & QALYS & $C E$ verdict \\
\hline COM & 8,753 & 3.096 & ICER 90,387 & 8,930 & 3.084 & Dominated $^{\mathrm{b}}$ \\
\hline POM & 8,622 & 3.095 & Most affordable & 8,834 & 3.084 & Most affordable \\
\hline 85, SOFPT & Costs $(€)$ & QALYS & $C E$ verdict & Costs $(€)$ & QALYS & CE verdict \\
\hline COM & 9,107 & 3.065 & ICER $101,120^{\mathrm{a}}$ & 9,084 & 3.072 & Dominated $^{\mathrm{b}}$ \\
\hline POM & 8,975 & 3.064 & Most affordable & 8,993 & 3.072 & Most affordable \\
\hline
\end{tabular}

Notes: ${ }^{a}$ COM probably not cost-effective in comparison to POMA in Finland. 'bominated, POMB is more or as effective and less costly than COM.

Abbreviations: CE, cost-effectiveness; COM, conventional osteoporosis management; ICER, incremental cost-effectiveness ratio; PEUS, pulse-echo ultrasonography; POFPT, primary osteoporotic fracture prevention treatment; POM, proposed osteoporosis management; POMA, proposed osteoporosis management pathway A; POMB, proposed osteoporosis management pathway B; QALY, quality-adjusted life year; SOFPT, secondary osteoporotic fracture prevention treatment.

patient group). The respective potential annual cost savings with POMB could be $€ 3.0(€ 2.1-3.8)$ million.

\section{Cost-effectiveness}

COM resulted in a marginal average QALY gain of 0.001 in comparison with POMA. Due to the negligible QALY gain and additional costs, COM was not cost-effective (the incremental cost-effectiveness ratios range from $€ 60,000$ to $308,000 /$ QALY gained) vs. POMA with the common willingness-to-pay threshold values. However, POMB dominated COM, as it resulted in negligible or similar QALY gain with lower costs (Table 3).

\section{Sensitivity analyses}

Multiple one-way and multiway sensitivity analysis scenarios were used (Table 4).

For the COM vs. POMA comparison, these sensitivity analyses scenarios included the following:

- A. Base case

- B. Mean T-score of -3.5 (severe osteoporosis)

- C. No discounting

- D. Discounting 5\%/year

- E. $50 \%$ initiate FPT

- F. $75 \%$ initiate FPT

- G. $10 \%$ adherent to FPT at 5 years

- H. $30 \%$ adherent to FPT at 5 years

- I. No disutility due to FPT

- J. DXA cost of $€ 124.00$ (the most affordable cost based on the cost review)
- K. DXA cost of $€ 381.26$ (the expected cost based on the cost review)

- L. PEUS test cost assumption of $€ 20.00$

- M. PEUS test cost assumption of $€ 35.00$

- N. Institutionalization costs of $€ 154.00 /$ day (elderly home $)^{63}$

- O. Fracture costs decreased by $25 \%$

- P. Fracture costs increased by $25 \%$

- Q. No travel costs included (direct health care costs only)

- R. Travel costs doubled

- S. DXA-related travel costs doubled

- T. Mean of sensitivity analysis scenarios B-S.

For the COM vs. POMB comparison, the reported sensitivity analysis scenarios included the following:

- U. Base case

- V. Mean T-score of -3.5 (severe osteoporosis)

- W. $30 \%$ adherent to FPT at 5 years

- X. No travel costs

- Y. No disutility due to FPT.

Based on the sensitivity analyses, the results were most sensitive to the large-scale changes in FPT (initiation proportion, disutility), DXA (cost, traveling), and T-score. Yet, POM remained the most cost-effective option and the base case analyses were conservative (i.e., did not benefit POM). For example, the analyses demonstrated that osteoporosis should be detected early and preferably before the first osteoporotic fracture, baseline T-score has significant impact on the costeffectiveness, FPT should be initiated for osteoporosis and 
Table 4 Sensitivity analyses presenting incremental cost-effectiveness ratios and their changes: COM pathway vs. POM pathways

\begin{tabular}{|c|c|c|c|c|c|c|c|c|c|c|}
\hline \multirow{2}{*}{$\begin{array}{l}\text { Outcome } \\
\text { Population }\end{array}$} & \multicolumn{5}{|c|}{ ICER (€/QALY gained) COM vs. POMA } & \multicolumn{5}{|c|}{ Relative change in the ICER } \\
\hline & $\begin{array}{l}65 \text { years, } \\
\text { SOFPT }\end{array}$ & $\begin{array}{l}75 \text { years, } \\
\text { POFPT }\end{array}$ & $\begin{array}{l}75 \text { years, } \\
\text { SOFPT }\end{array}$ & $\begin{array}{l}85 \text { years, } \\
\text { POFPT }\end{array}$ & $\begin{array}{l}85 \text { years, } \\
\text { SOFPT }\end{array}$ & $\begin{array}{l}65 \text { years, } \\
\text { SOFPT }\end{array}$ & $\begin{array}{l}75 \text { years, } \\
\text { POFPT }\end{array}$ & $\begin{array}{l}75 \text { years, } \\
\text { SOFPT }\end{array}$ & $\begin{array}{l}85 \text { years, } \\
\text { POFPT }\end{array}$ & $\begin{array}{l}85 \text { years, } \\
\text { SOFPT }\end{array}$ \\
\hline A & 307,527 & 60,478 & 87,808 & 90,387 & 101,120 & $0 \%$ & $0 \%$ & $0 \%$ & $0 \%$ & $0 \%$ \\
\hline B & 106,632 & 36,329 & 36,437 & 71,102 & 75,406 & $-65 \%$ & $-40 \%$ & $-59 \%$ & $-21 \%$ & $-25 \%$ \\
\hline C & 277,233 & 50,788 & 70,979 & 80,992 & 89,877 & $-10 \%$ & $-16 \%$ & $-19 \%$ & $-10 \%$ & $-11 \%$ \\
\hline $\mathrm{D}$ & 370,968 & 67,643 & 100,197 & 99,678 & $|08,87|$ & $21 \%$ & $12 \%$ & $14 \%$ & $10 \%$ & $8 \%$ \\
\hline E & 736,976 & 153,302 & 222,338 & 205,894 & 223,221 & $140 \%$ & $153 \%$ & $153 \%$ & $128 \%$ & $121 \%$ \\
\hline $\mathrm{F}$ & 455,350 & 91,241 & 129,624 & $|29,7| \mid$ & $|4|, \mid 49$ & $48 \%$ & $51 \%$ & $48 \%$ & $44 \%$ & $40 \%$ \\
\hline G & $44 I, 273$ & 89,747 & 128,015 & 120,965 & 133,275 & $43 \%$ & $48 \%$ & $46 \%$ & $34 \%$ & $32 \%$ \\
\hline $\mathrm{H}$ & 251,611 & 44,868 & 64,221 & 76,150 & 82,704 & $-18 \%$ & $-26 \%$ & $-27 \%$ & $-16 \%$ & $-18 \%$ \\
\hline I & 301,715 & 162,729 & 121,130 & 237,198 & 235,259 & $-2 \%$ & $169 \%$ & $38 \%$ & $162 \%$ & $133 \%$ \\
\hline J & 386,754 & 79,653 & 110,185 & 115,000 & 124,890 & $26 \%$ & $32 \%$ & $25 \%$ & $27 \%$ & $24 \%$ \\
\hline $\mathrm{K}$ & 867,136 & 176,648 & 251,845 & 234,590 & 253,622 & $182 \%$ & $192 \%$ & $187 \%$ & $160 \%$ & $151 \%$ \\
\hline $\mathrm{L}$ & 428,712 & 77,996 & 113,259 & II 2,764 & $|23,4| 3$ & $39 \%$ & $29 \%$ & $29 \%$ & $25 \%$ & $22 \%$ \\
\hline$M$ & 340,647 & 69,718 & 100,488 & $|02,23|$ & III,567 & $11 \%$ & $15 \%$ & $14 \%$ & $13 \%$ & $10 \%$ \\
\hline $\mathrm{N}$ & 300,647 & 57,528 & 78,936 & 90,864 & 98,197 & $-2 \%$ & $-5 \%$ & $-10 \%$ & $1 \%$ & $-3 \%$ \\
\hline 0 & 294,639 & 58,489 & 81,381 & 90,739 & 98,035 & $-4 \%$ & $-3 \%$ & $-7 \%$ & $0 \%$ & $-3 \%$ \\
\hline$P$ & 318,927 & 63,252 & 92,466 & 94,118 & 104,055 & $4 \%$ & $5 \%$ & $5 \%$ & $4 \%$ & $3 \%$ \\
\hline Q & $18 \mid, 697$ & 29,905 & 42,728 & 53,457 & 58,394 & $-41 \%$ & $-51 \%$ & $-51 \%$ & $-41 \%$ & $-42 \%$ \\
\hline $\mathrm{R}$ & 502,468 & 91,773 & $130,20 \mid$ & 128,363 & 139,178 & $63 \%$ & $52 \%$ & $48 \%$ & $42 \%$ & $38 \%$ \\
\hline S & 437,742 & 96,665 & $|4|, 486$ & 136,277 & 149,386 & $42 \%$ & $60 \%$ & $61 \%$ & $51 \%$ & $48 \%$ \\
\hline $\mathrm{T}$ & 384,666 & 82,040 & I I 0,722 & 119,499 & 129,033 & $25 \%$ & $36 \%$ & $26 \%$ & $32 \%$ & $28 \%$ \\
\hline COM vs. & 65 years, & 75 years, & 75 years, & 85 years, & 85 years, & 65 years, & 75 years, & 75 years, & 85 years, & 85 years, \\
\hline POMB & SOFPT & POFPT & SOFPT & POFPT & SOFPT & SOFPT & POFPT & SOFPT & POFPT & SOFPT \\
\hline U & Dom. & Dom. & Dom. & Dom. & Dom. & na & na & na & na & na \\
\hline V & Dom. & $|69,93|$ & 54,706 & 425,108 & 514,020 & na & na & na & na & na \\
\hline W & Dom. & Dom. & Dom. & Dom. & Dom. & na & na & na & na & na \\
\hline$x$ & Dom. & Dom. & Dom. & Dom. & Dom. & na & na & na & na & na \\
\hline Y & 149,093 & 125,290 & 63,170 & I 78,992 & 167,249 & na & na & na & na & na \\
\hline
\end{tabular}

Notes: A. Base case; B. mean T-score -3.5; C. discounting 0\%/year; D. discounting 5\%/year; E. 50\% initiate fracture prevention treatment; F. $75 \%$ initiate fracture prevention treatment; G. $10 \%$ adherent to fracture prevention treatment at 5 years; $\mathrm{H}$. $30 \%$ adherent to fracture prevention treatment at 5 years; I. no disutility due to fracture prevention treatment; J. DXA €124.00; K. DXA €38I.26; L. PEUS test $€ 20.00 ;$ M. PEUS test $€ 35.00 ; \mathrm{N}$. institutionalized $€ I 54.00 /$ day; O. fracture costs $-25 \%$; P. fracture costs $+25 \%$; Q. no travel costs; R. travel costs doubled; S. DXA travel costs doubled; T. mean of sensitivity analysis scenarios; U. base case; V. mean T-score -3.5 ; W. $30 \%$ adherent to fracture prevention treatment at 5 years; $X$. no travel costs; $Y$. no disutility due to fracture prevention treatment.

Abbreviations: COM, conventional osteoporosis management; Dom., POM more effective and less costly vs. COM; DXA, dual-energy X-ray absorptiometry; ICER, incremental cost-effectiveness ratio; PEUS, pulse-echo ultrasonography; POFPT, primary osteoporotic fracture prevention treatment; POMA, proposed osteoporosis management A (PEUS used for testing and diagnosis); POMB, proposed osteoporosis management B (PEUS used for testing); QALY, quality-adjusted life year; SOFPT, secondary osteoporotic fracture prevention treatment; na, not applicable.

used persistently, DXA travel has the largest impact regarding traveling costs, and any increase in the potentially underestimated DXA-associated costs can significantly decrease the cost-effectiveness of COM.

Based on the simulations for different base case testing outcomes, the expected additional cost/patient due to the FPT assignment being based on the results of a slightly inaccurate PEUS was small (€35-61 for POMA, average being $€ 46$, and $€ 0-22$ for POMB, average being $€ 7$, over the 10 years; varying by risk group) in comparison with the total costs or cost savings. Based on a face validity assessment scenario with $100 \%$ sensitivity-specificity for PEUS, the QALYs were similar for COM and POM, and the expected average cost difference of $€ 165$ (average value's range $€ 162-168$ dependent on the patient group) in favor of POM was observed (i.e., POM would be strongly dominant in the case of similar sensitivity-specificity of PEUS and DXA). On the other hand, in an unrealistic extreme sensitivity analysis scenario with $82 \%$ sensitivity-specificity threshold for PEUS, the average QALY difference increased with 0.001 between COM and POM in comparison to the COM vs. POMA base case, and the average cost difference decreased to $€ 91$ between COM and POM, resulting in $€ 42,604 / \mathrm{QALY}$ gained for COM vs. POM.

POMA had 96\%-100\% probabilities for cost-effectiveness vs. COM at the $€ 24,406$ willingness to pay/QALY gained and depending on the patients modeled (Figure 3). The respective results for POMB were 95\%-100\%. With 
A

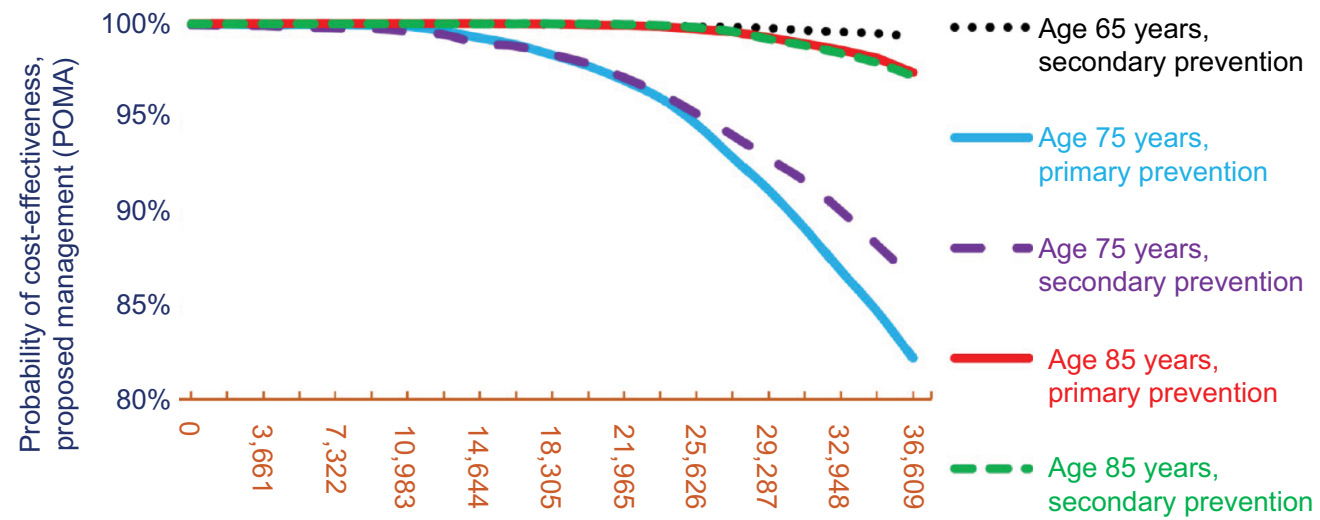

Willingness to pay $(€)$ per quality-adjusted life year gained

B

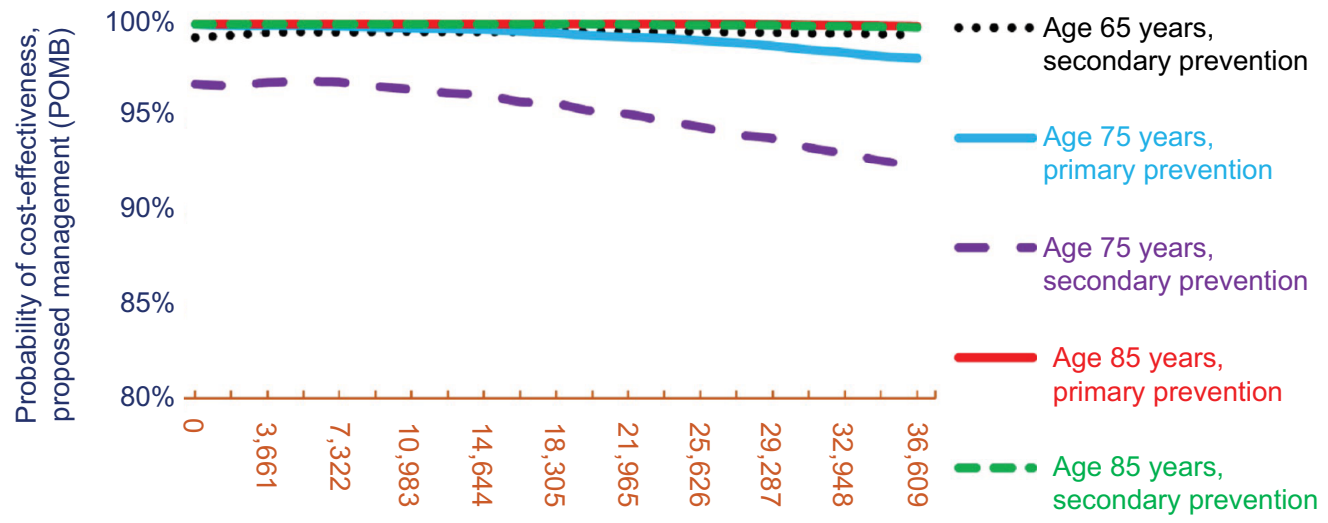

Willingness to pay $(€)$ per quality-adjusted life year gained

Figure 3 Cost-effectiveness acceptability frontiers with sensible willingness-to-pay values of $€ 0-36,609$ per quality-adjusted life year gained present high probabilities (82\%-100\%) of cost-effectiveness for POMA (upper part [A], PEUS is used for the osteoporosis testing and diagnosis) and POMB (lower part [B], patient tested with PEUS). Abbreviations: PEUS, pulse-echo ultrasound technology; POMA, proposed osteoporosis management pathway A; POMB, proposed osteoporosis management pathway $B$.

the $€ 36,609$ willingness to pay/QALY gained, POMA had $82 \%-99 \%$ probabilities for cost-effectiveness. The respective probabilities for POMB were $92 \%-100 \%$. With the $€ 0$ willingness to pay/QALY gained, POMA and POMB had $100 \%$ and $97 \%-100 \%$ probabilities for cost-effectiveness, respectively.

Finally, for descriptive purposes, Table 5 reports the number of simulated fractures based on the treatment allocation and over the maximum time horizon of 10 years (mortality included) for a 75-year-old female without any significant clinical risk factors and with an average T-score of -2.8 . Generally, the most frequent fractures include hip and other fractures. Given the incidence and unit cost of fractures, the highest expected cost impact for the first 3 months after a fracture was estimated for hip fractures.

\section{Discussion}

Recently, the cost-effectiveness of FPTs has been reviewed, ${ }^{39}$ and the cost-effectiveness of osteoporosis testing and FPT has been debated. ${ }^{30}$ This study assessed for the first time the incremental cost-effectiveness of two proposed (POMs: FRAX $\rightarrow$ PEUS-when-needed $\rightarrow$ DXA-when-needed) vs. conventional (COM: FRAX $\rightarrow$ DXA-when-needed) osteoporosis management pathways in Finland using generic alendronate FPT for osteoporotic individuals. POMs could result in payer cost savings, regardless of whether PEUS is used for both osteoporosis testing-diagnosing (POMA) or testing only (POMB). POM and the societal perspective appraised in countries such as Sweden would result in additional cost savings, as most of the indirect costs would be associated with the DXA measurement. 
Table 5 Simulated fractures during the maximum time horizon of 10 years for a 75 -year-old non-smoking female with no parental hip fracture, no oral glucocorticoid, no rheumatoid arthritis, no alcoholism, and an average T-score of -2.8

\begin{tabular}{|c|c|c|c|}
\hline \multicolumn{4}{|l|}{ Patient allocation } \\
\hline FPT, osteoporosis (true positive) & Mean & $95 \% \mathrm{Cl}$ & Expected first 3-month cost $(€)^{\mathbf{a}}$ \\
\hline Hip fractures & 0.058 & $0.036-0.092$ & 453 \\
\hline Vertebral fractures & 0.012 & $0.000-0.025$ & 86 \\
\hline Wrist fracture & 0.008 & $0.000-0.021$ & 29 \\
\hline Other fracture & 0.022 & $0.000-0.07 \mid$ & 76 \\
\hline Sum & 0.100 & & 644 \\
\hline No FPT, osteoporosis (false negative) & Mean & $95 \% \mathrm{Cl}$ & Expected first 3-month cost $(€)^{\mathrm{a}}$ \\
\hline Hip fractures & 0.075 & $0.059-0.118$ & 586 \\
\hline Vertebral fractures & 0.015 & $0.000-0.030$ & 107 \\
\hline Wrist fracture & 0.010 & $0.000-0.025$ & 36 \\
\hline Other fracture & 0.022 & $0.000-0.070$ & 75 \\
\hline Sum & 0.122 & & 804 \\
\hline $\begin{array}{l}\text { FPT, without osteoporosis (false positive) or no FPT, without } \\
\text { osteoporosis (true negative) }\end{array}$ & Mean & $95 \% \mathrm{Cl}$ & Expected first 3-month cost $(€)^{\mathrm{a}}$ \\
\hline Hip fractures & 0.017 & $0.010-0.026$ & $|3|$ \\
\hline Vertebral fractures & 0.006 & $0.000-0.011$ & 41 \\
\hline Wrist fracture & 0.004 & $0.000-0.010$ & 14 \\
\hline Other fracture & 0.008 & $0.000-0.027$ & 29 \\
\hline Sum & 0.035 & & 215 \\
\hline
\end{tabular}

Note: 'Expected first 3-month costs were estimated for the demonstration purposes only and were based on the simulated mean incidence over the maximum 10 years' time horizon and the average unit costs of first 3 months with a fracture.

Abbreviation: FPT, fracture prevention treatment (alendronate, persistence accounted for).

The incremental cost-effectiveness ratios of COM vs. POMA were high and POMB dominated COM, which indicated that COM would not be cost-effective in comparison to POMs in the Finnish setting or in most of the European settings. Although COM produced marginally more QALYs (0.001) vs. POMA due to false positives and negatives related to PEUS use, it was far too expensive to achieve reasonable cost-effectiveness. At $€ 24,406$ willingness to pay/QALY gained, POM had $95 \%-100 \%$ cost-effectiveness probability.

The osteoporosis management costs were reduced when PEUS was included. The additional cost due to the FPT assignment being based on the PEUS was small in comparison with the total costs. The results were sensitive to the large-scale changes in the FPT, DXA-associated costs, and T-score. However, POMs remained cost-effective vs. COM in the extensive sensitivity analyses.

Based on the explorative analyses, osteoporosis should be detected early and preferably before osteoporotic fracture, T-score has significant impact on the cost-effectiveness, and FPT should be initiated for osteoporosis and used persistently. If 40,000 women were screened per year and FPT was initiated for the osteoporotic, POMA or POMB could easily result in average annual savings of $\_€ 5$ or $€ 3$ million in the limited social and health care budgets, respectively.

However, evaluation with decision analytical modeling is a simplification of the complex reality. A typical approach is analysis using trial-based efficacy outcomes alone and a demonstration that the intervention may work in optimal and controlled settings. A more difficult and realistic modeling framework was carried out here. As examples, real-world, evidence-based health-related quality of life and persistence, and conservative sensitivity and specificity thresholds for PEUS were used.

Further conservative assumptions were made. For example, DXA measurement was assumed to be $100 \%$ accurate, which may not be true due to various human errors, calibration issues or hardware faults. Alendronate FPT was assumed to result in disutility. Sensitivity and specificity of PEUS were accounted for. A partial consequence of this was that especially POMA led to marginally fewer QALYs in comparison with COM. However, the average difference was only 0.001 QALYs $(0.03 \%)$, which is a negligible difference.

In a larger scope, the PEUS ${ }^{25-29}$ just recently received a new reimbursement code (0508T: pulse-echo ultrasound bone density measurement resulting in indicator of axial bone mineral density, tibia) from the American Medical Association. ${ }^{72}$ Considering the previously published evidence on the PEUS method, ${ }^{25,26,29}$ the American Medical Association reimbursement, ${ }^{72}$ and the cost-effectiveness results reported here, the use of PEUS as a part of the POM pathway for screening and diagnostics in 65- to 80-year-old postmenopausal Caucasian women is supported. 
In addition, access to DXA can be more expensive than assumed here, or even impossible in remote areas. Using an affordable cost of DXA based on the current DXA tests and potentially underestimated traveling costs, PEUS can easily be cost-effective at a cost-per-single-site test of up to around $€ 110$ (i.e., 2.2 times the probably overestimated cost used in the base case) in all modeled cohorts. If the costs associated with DXA were higher (e.g., if there is a long distance to the nearest DXA device), an even higher price per PEUS test could be economically justifiable. The Finnish results of POMs with PEUS may underestimate the savings in other countries, but studies in other settings regarding the traveling cost and the optimal location of DXA are needed to confirm such a conclusion.

Finally, more flexible and agile, economically justifiable methods for screening, detecting, and predicting the course of any important or frequent disease or situation are supported governmentally by the encompassing digitalization of social and health care services as well as by the secondary use of health and social welfare data in Finland. More specifically, the assessment and implementation of digitalized customerresponsive health and social care services including, for example, Omahoito ja Digitaaliset Arvopalvelut (ODA) digitalized services for primary health and social care, ${ }^{73,74}$ together with the associated Health Village are under their way. Moreover, the secondary use data lakes covering social and health data have been tested through so-called Isaacus pre-production projects, ${ }^{75,76}$ and the remote use platforms for the data lakes together with scientist tools are being built to enable knowledge management and research. ${ }^{75}$ Tools with novel data collecting software such as PEUS ${ }^{25-29}$ are likely to fit well to this ongoing development.

\section{Conclusion}

A significant unmet need for new, safe, and effective osteoporosis diagnosis exists. This cost-utility analysis indicated that FPT should be initiated for osteoporotic patients and used persistently, and that PEUS is a cost-saving method with acceptable results in the osteoporosis testing-diagnosing process or the testing process alone, as POMs can result in cost savings with very similar health outcomes in comparison with COM. POM probably also provides a cost-effective alternative for osteoporosis management in other countries utilizing DXA measurements, but further studies in other settings are needed to confirm this conclusion.

\section{Acknowledgments}

The study was financially supported by Bone Index Finland Ltd, Kuopio, Finland. ESiOR Oy (Kuopio, Finland) carries out studies, statistical analysis, consultancy, education, reporting, and health economic evaluations for several pharmaceutical, food industry, diagnostics and device companies, hospitals, consultancies, and academic institutions, including the producers and marketers of FPTs. ESiOR received financial support for the study from Bone Index Finland Ltd. The financial supporter (Bone Index Finland Ltd, Kuopio, Finland) participated in the identification, design, conduct, and reporting of the analysis.

\section{Author contributions}

Management (ES, OR), conceptualization (ES, OR, JPK, HK), design (all), data acquisition (ES, OR, JPK, PM), data analysis (ES) and interpretation (all), health economic modeling (ES), initial drafting (ES), and critical revision (all). All authors contributed toward data analysis, drafting and revising the paper and agree to be accountable for all aspects of the work.

\section{Disclosure}

ES, PM, or TH did not receive any direct financial support as individuals. HK works as an invited member of the national Käypä Hoito care guidance working group for osteoporosis. HK has received consultancy fees and lecture payments from Amgen Ltd and Eli Lilly ltd, and is a partner of Bone Index. ES, PM, and TH are employees of ESiOR Oy, Kuopio, Finland. ES and TH are also partners and directors of ESiOR. OR and JPK are employees and partners of Bone Index. Bone Index is the manufacturer and marketer of PEUS (Bindex ${ }^{\circledR}$ ). The authors report no other conflicts of interest in this work.

\section{References}

1. Nelson HD, Helfand M, Woolf SH, Allan JD. Screening for postmenopausal osteoporosis: a review of the evidence for the U.S. Preventive Services Task Force. Ann Intern Med. 2002;137:529-541.

2. Nelson HD, Haney EM, Chou R, et al. Screening for Osteoporosis: Systematic Review to Update the 2002 U.S. Preventive Services Task Force Recommendation [Internet]. Rockville (MD): Agency for Healthcare Research and Quality (US); 2010 July. Report No. 10-05145-EF-1.

3. Alhava E. Epidemiology of osteoporosis in Finland. Duodecim. 2004;120:2149-2150.

4. NHS Choices. Osteoporosis. NHS; [updated June 20, 2016; cited January 19, 2018]. Available from: http://www.nhs.uk/Conditions/ Osteoporosis/Pages/Introduction.aspx. Accessed January 19, 2018.

5. Osteoporoosi (online) [Osteoporosis]. Suomalaisen Lääkäriseuran Duodecimin, Suomen Endokrinologiyhdistyksen ja Suomen Gynekologiyhdistyksen asettama työryhmä [Working Group by Finnish Medical Society Duodecim, Finnish Society for Endocrinology and Finnish Society for Gynaegology]; [updated February 14, 2018; cited February 15, 2018]. Helsinki: Suomalainen Lääkäriseura Duodecim. Available from: http://www.kaypahoito.fi. Accessed February 15, 2018.

6. Sund R, Honkanen R, Johansson H, et al. Evaluation of the FRAX model for hip fracture predictions in the population-based Kuopio Osteoporosis Risk Factor and Prevention Study (OSTPRE). Calcif Tissue Int. 2014;95:39-45. 
7. World Health Organization. Assessment of fracture risk and its application to screening for postmenopausal osteoporosis. Technical report series 843. Geneva: WHO; 1994.

8. Suomen virallinen tilasto (SVT) [webpage on the Internet]. Väestörakenne [verkkojulkaisu] [Population Structure]; [updated September 22, 2017; cited January 19, 2018]. Helsinki: Tilastokeskus. Available from: http://www.stat.fi/til/vaerak/index.html. Accessed January 19, 2018.

9. Kannus P, Niemi S, Parkkari J, Sievänen H. Declining incidence of fall-induced ankle fractures in elderly adults: finnish statistics between 1970 and 2014. Arch Orthop Trauma Surg. 2016;136:1243-1246.

10. Kannus P, Niemi S, Sievänen H, Parkkari J. Continuous decline in incidence of distal humeral fracture of older women in Finland. Aging Clin Exp Res. 2017;29:467-471.

11. Kannus P, Parkkari J, Niemi S, Sievänen H. Low-trauma knee fractures in older Finnish women between 1970 and 2013. Aging Clin Exp Res. 2016;28:665-668.

12. Korhonen N, Niemi S, Parkkari J, Sievänen H, Palvanen M, Kannus P. Continuous decline in incidence of hip fracture: nationwide statistics from Finland between 1970 and 2010. Osteoporos Int. 2013;24 1599-603.

13. Kannus P, Parkkari J, Niemi S, Sievänen H. Low-trauma pelvic fractures in elderly finns in 1970-2013. Calcif Tissue Int. 2015;97:577-580.

14. Korhonen N, Kannus P, Niemi S, Parkkari J, Sievänen H. Rapid increase in fall-induced cervical spine injuries among older Finnish adults between 1970 and 2011. Age Ageing. 2014;43:567-571.

15. Kannus P, Niemi S, Palvanen M, Sievänen H, Parkkari J, Järvinen M. Rising incidence of low-trauma fractures of the calcaneus and foot among Finnish older adults. J Gerontol A Biol Sci Med Sci. 2008;63:642-645.

16. Ensrud KE, Palermo L, Black DM, et al. Hip and calcaneal bone loss increase with advancing age: longitudinal results from the study of osteoporotic fractures. J Bone Miner Res. 1995;10:1778-1787.

17. Jones G, Nguyen T, Sambrook P, Kelly PJ, Eisman JA. Progressive loss of bone in the femoral neck in elderly people: longitudinal findings from the Dubbo osteoporosis epidemiology study. Brit Med J. 1994;309:691-695.

18. Riggs BL, Melton LJ III. Involutional osteoporosis. $N$ Engl J Med. 1986;314:1676-1686

19. Kelasto. Lääkekorvausten saajat ja reseptitiedot 2016 [Reimbursemen Receivers and Prescriptions 2015]. Helsinki: Kansaneläkelaitos; 2018

20. Compston J, Cooper A, Cooper C, et al; National Osteoporosis Guideline Group (NOGG). UK clinical guideline for the prevention and treatment of osteoporosis. Arch Osteoporos. 2017;12:43.

21. NOGG 2017: Clinical guideline for the prevention and treatment of osteoporosis; [updated 2017 March; cited January 19, 2018]. Available from: https://www.shef.ac.uk/NOGG/NOGG\%20Guideline\%202017. pdf. Accessed January 19, 2018.

22. Kröger H. FRAX fracture risk calculator in the diagnostics and treatment of osteoporosis. Duodecim. 2013;129:1149-1152.

23. FRAX. Fracture Risk Assessment Tool. Finland; [updated na; cited January 19, 2018]. Available from: http://www.shef.ac.uk/FRAX/tool. aspx. Accessed January 19, 2018.

24. Nguyen TV, Center JR, Eisman JA. Osteoporosis: underrated, underdiagnosed and undertreated. Med J Aust. 2004;180:S18-S22.

25. Schousboe JT, Riekkinen O, Karjalainen J. Prediction of hip osteoporosis by DXA using a novel pulse-echo ultrasound device. Osteoporos Int. 2017;28:85-93.

26. Karjalainen JP, Riekkinen O, Töyräs J, Jurvelin JS, Kröger H. New method for point-of-care osteoporosis screening and diagnostics. Osteoporos Int. 2016;27:971-977.

27. Behrens M, Felser S, Mau-Moeller A, et al. The Bindex ${ }^{\circledR}$ ultrasound device: reliability of cortical bone thickness measures and their relationship to regional bone mineral density. Physiol Meas. 2016;37:1528-1540

28. Karjalainen JP, Riekkinen O, Töyräs J, et al. Multi-site bone ultrasound measurements in elderly women with and without previous hip fractures. Osteoporos Int. 2012;23:1287-1295.
29. Karjalainen JP, Riekkinen O, Kröger H. Pulse-echo ultrasound method for detection of post-menopausal women with osteoporotic BMD. Osteoporos Int. Epub 2018 Feb 19.

30. Blain H, Masud T, Dargent-Molina P, et al; EUGMS Falls and Fracture Interest Group; International Association of Gerontology and Geriatrics for the European Region (IAGG-ER); European Union of Medical Specialists (EUMS); Fragility Fracture Network (FFN); European Society for Clinical and Economic Aspects of Osteoporosis and Osteoarthritis (ESCEO), and; International Osteoporosis Foundation (IOF). A comprehensive fracture prevention strategy in older adults: the European Union Geriatric Medicine Society (EUGMS) statement. Aging Clin Exp Res. 2016;28:797-803.

31. Soini E, Joutseno J, Sumelahti ML. Cost-utility of first-line diseasemodifying treatments for relapsing-remitting multiple sclerosis. Clin Ther: 2017;39:537-557.

32. Soini E. Biologisten lääkkeiden kustannusvaikuttavuus nivelpsoriaasin hoidossa [Cost-Effectiveness of Biologic Treatments in Joint Psoriasis]. Käypä hoito [Current Care Criteria]: Lisätietoa [Additional information]; [updated March 1, 2017; cited January 19, 2018]. Available from: http://www.kaypahoito.fi/web/kh/suositukset/suositus?id=nix02465\&s uositusid=hoi50062. Accessed January 19, 2018.

33. Fimean suositus lääkkeiden hoidollisen ja taloudellisen arvon arvioinnista [Fimea recommendation for the assessment of the therapeutic and economic value of pharmaceuticals]. Kuopio: Fimea kehittää, arvioi ja informoi -julkaisusarja [Serial Publication Fimea Develops, Assesses and Informs]; 2/2012.

34. Terveystalousselvityksen selvityksen laatiminen lääkevalmisteen korvattavuus- ja tukkuhintahakemukseen [Composing health economic evaluation for the pricing and reimbursement application], 31.1.2017. Helsinki: Lääkkeiden hintalautakunta; 2017.

35. Briggs A, Claxton C, Sculpher M. Decision Modelling for Health Economic Evaluation. Oxford: Oxford University Press; 2008.

36. Soini E, Hallinen T, Brignone M, et al. Cost-utility analysis of vortioxetine versus agomelatine, bupropion SR, sertraline and venlafaxine XR after treatment switch in major depressive disorder in Finland. Expert Rev Pharmacoecon Outcomes Res. 2017;17:293-302.

37. Hans DB, Shepherd JA, Schwartz EN, et al. Peripheral dual-energy X-ray absorptiometry in the management of osteoporosis: the 2007 ISCD Official Positions. J Clin Densitom. 2008;11:188-206.

38. Krieg MA, Barkmann R, Gonnelli S, et al. Quantitative ultrasound in the management of osteoporosis: the 2007 ISCD Official Positions. J Clin Densitom. 2008;11:163-187.

39. Hiligsmann M, Evers SM, Ben Sedrine W, et al. A systematic review of cost-effectiveness analyses of drugs for postmenopausal osteoporosis. Pharmacoeconomics. 2015;33:205-224.

40. Lääkehaku [Drug search]. Helsinki: Kansaneläkelaitos; 2018.

41. Fleurence RL, Hollenbeak CS. Rates and probabilities in economic modelling: transformation, translation and appropriate application. PharmacoEconomics. 2007;25:3-6.

42. Hiligsmann M, McGowan B, Bennett K, Barry M, Reginster JY. The clinical and economic burden of poor adherence and persistence with osteoporosis medications in Ireland. Value Health. 2012;15:604-612.

43. Nayak S, Roberts MS, Greenspan SL. Cost-effectiveness of different screening strategies for osteoporosis in postmenopausal women. Ann Intern Med. 2011;155:751-761.

44. Sund R, Juntunen M, Lüthje P, et al. PERFECT - Lonkkamurtuma [PERFECT - Hip fracture]. Helsinki: STAKESin työpapereita [STAKES working papers]; 2008;18:1-31.

45. Stevenson M, Jones ML, De Nigris E, et al. A systematic review and economic evaluation of alendronate, etidronate, risedronate, raloxifene and teriparatide for the prevention and treatment of postmenopausal osteoporosis. Health Technol Assess. 2005;9:1-160.

46. Hiligsmann M, Ethgen O, Bruyère $O$, et al. Development and validation of a Markov microsimulation model for the economic evaluation of treatments in osteoporosis. Value Health. 2009;12:687-696.

47. Rabenda V, Mertens R, Fabri V, Richy F, Gathon HJ, Reginster JY. Adherence to bisphosphonates therapy and hip fracture risk in osteoporotic women. Osteroporos Int. 2008;19:811-818. 
48. Suomen virallinen tilasto (SVT) [webpage on the Internet]. Kuolleet [Mortality]; [updated April 28, 2017; cited January 19, 2018]. Helsinki: Tilastokeskus. Available from: http://www.stat.fi/til/kuol/index.html. Accessed January 19, 2018.

49. Suomen virallinen tilasto (SVT) [webpage on the Internet]. Kuolemansyyt [Causes of death]; [updated December 29, 2017; cited January 19, 2018]. Helsinki: Tilastokeskus. Available from: http://www.stat.fi/til/ ksyyt/index.html. Accessed January 19, 2018.

50. Haentjens P, Magaziner J, Colón-Emeric CS, et al. Meta-analysis: excess mortality after hip fracture among older women and men. Ann Intern Med. 2010;152:380-390.

51. Saarni SI, Härkänen T, Sintonen H, et al. The impact of 29 chronic conditions on health-related quality of life: a general population survey in Finland using 15D and EQ-5D. Qual Life Res. 2006;15:1403-1414.

52. Hiligsmann M, Ethgren O, Richy F, Reginster JY. Utility values associated with osteoporotic fracture: a systematic review of the literature. Calcif Tissue Int. 2008;82:288-292.

53. Baltic guideline for economic evaluation of pharmaceuticals (pharmacoeconomic analysis); [updated August 8, 2002; cited January 19, 2018]. Available from: https://www.ispor.org/PEguidelines/source/ Baltic-PE-guideline.pdf. Accessed January 19, 2018.

54. Belgian Health Care Knowledge Centre. Belgian Guidelines for Economic Evaluations and Budget Impact Analyses. 2nd ed. Brussels: Belgian Health Care Knowledge Centre (KCE). 2012.

55. Collège des Économistes de la Santé. French Guidelines for the Economic Evaluation of Health Care Technologies. Paris: Collège des Économistes de la Santé; 2004:1-90.

56. College voor zorgverzekeringen. Guidelines for pharmacoeconomic research, updated version. Diemen: College voor zorgverzekeringen; 2006:1-14.

57. Health Information and Quality Authority. Guidelines for the Economic Evaluation of Health Technologies in Ireland. Cork: Health Information and Quality Authority; 2010:1-75.

58. Institut für Pharmaökonomische Forschung. Guidelines on health economic evaluation Vienna: Institut für Pharmaökonomische Forschung; 2006:1-11.

59. López-Bastida J, Oliva J, Antoñanzas F, et al. Spanish recommendations on economic evaluation of health technologies. Eur J Health Econ. 2010;11:513-520.

60. National Institute for Health and Care Excellence. Guide to the Methods of Technology Appraisal 2013. London: National Institute for Health and Care Excellence; 2013.

61. Norwegian Medicines Agency. Guidelines on How to Conduct Pharmacoeconomic Analyses. Norwegian Medicines Agency; 2012:1-27.

62. Scottish Medicines Consortium. Guidance to Manufacturers for Completion of New Product Assessment Form. Scottish Medicines Consortium; 2007.

63. Kapiainen S, Väisänen A, Haula T. Terveyden- ja sosiaalihuollon yksikkökustannukset Suomessa vuonna 2011 [Health and Social Care Costs in Year 2011 in Finland]. Helsinki: Terveyden ja hyvinvoinnin laitos; 2014.
64. Suomen virallinen tilasto (SVT) [webpage on the Internet]. Julkisten menojen hintaindeksi [Public Expenditure Cost Index]; [updated October 27, 2017; cited January 19, 2018]. Helsinki: Tilastokeskus. Available from: http://www.stat.fi/til/jmhi/index.html. Accessed January 19, 2018.

65. Hujanen T, Kapiainen S, Tuominen U, Pekurinen M. Terveydenhuollon yksikkökustannukset Suomessa vuonna 2006 [Health Care Unit Costs in Year 2006 in Finland]. Helsinki: Stakesin Työpapereita; 2008.

66. Suomen virallinen tilasto (SVT) [webpage on the Internet]. Kuluttajahintaindeksi [Consumer Price Index]; [updated January 15, 2018; cited January 19, 2018]. Helsinki: Tilastokeskus. Available from: http://www. stat.fi/til/khi/index.html. Accessed January 19, 2018.

67. Soini EJ, Hallinen T, Sokka AL, Saarinen K. Cost-utility of first-line actinic keratosis treatments in Finland. Adv Ther. 2015;32:455-476.

68. Soini E, Kukkonen J, Myllykangas M, Ryynänen OP. Contingent valuation of eight new treatments: What is the clinician's and politician's willingness to pay? Open Complement Med J. 2012;4:1-11.

69. Soini E. Kroonisen lymfaattisen leukemian hoidon kustannusvaikuttavuus Suomessa ja sen uudet tulkinnat: Kliininen kustannushyöty ja vaikuttavuusinvestoiminen [Cost Effectiveness of Chronic Lymphatic Leukaemia and Its New Interpretations: Clinical Cost Benefit and Impact Investment]. BestPractice Onkologia / Hematologia. 2016;5: 30-32.

70. Bank of Finland. Average Annual Exchange Courses in Year 2016. Helsinki: Bank of Finland; 2017.

71. Barton GR, Briggs AH, Fenwick EA. Optimal cost-effectiveness decisions: the role of the cost-effectiveness acceptability curve (CEAC), the cost-effectiveness acceptability frontier (CEAF), and the expected value of perfection information (EVPI). Value Health. 2008;11: 886-897.

72. American Medical Association. CPT ${ }^{\circledR}$ Category III Codes; [updated December 21, 2017; cited January 19, 2018]. Available from: https:// www.ama-assn.org/sites/default/files/media-browser/public/cpt/cptcategory3-codes-descriptors.pdf. Accessed January 19, 2018.

73. Prime Minister's Office. Finland, A Land of Solutions. Mid-Term Review. Government Action Plan 2017-2019. Finland: Government Publications $7 / 2017$.

74. Väätäinen S, Soini E, Arvonen S. Virtual hospital 2.0 - modelled cost-benefit assessment: towards potential economic efficiency with digitalization and customer-responsive services. eHealth 2018, The 23rd Finnish National Conference on Telemedecine and eHealth, The 23rd ISfTeH International Conference; page 37; March 15, 2018; Helsinki/ Stockholm/Helsinki: Finnish Society of Telemedicine and eHealth.

75. Soini E, Hallinen T, Kekoni A, et al. Efficient secondary use of representative social and health care data in Finland: Isaacus data lake, analytics and knowledge management pre-production project. Value Health. 2017;20:A777.

76. Hallinen T, Soini E, Kekoni A, et al. Isaacus pre-production project: child protection process and placement decision. eHealth 2018, The 23rd Finnish National Conference on Telemedecine and eHealth, The 23rd ISfTeH International Conference; page 64; March 15, 2018; Helsinki/ Stockholm/Helsinki: Finnish Society of Telemedicine and eHealth.
ClinicoEconomics and Outcomes Research

\section{Publish your work in this journal}

ClinicoEconomics and Outcomes Research is an international, peerreviewed open-access journal focusing on health technology assessment, pharmacoeconomics and outcomes research in the areas of diagnosis, medical devices, and clinical, surgical and pharmacological intervention. The economic impact of health policy and health systems organization also constitute important areas of coverage. The manuscript management system is completely online and includes a very quick and fair peer-review system, which is all easy to use. Visit http://www.dovepress.com/testimonials.php to read real quotes from published authors. 